\title{
Genetic Variation for Grain Yield and Yield Related Traits in Tef [Eragrostis tef (Zucc.)Trotter] under Moisture Stress and Non-Stress Environments
}

\author{
Wondewosen Shiferaw $^{1}$, Alemayehu Balcha ${ }^{2 *}$, Hussen Mohammed $^{3}$ \\ ${ }^{1}$ Jinka Agricultural Research Centre, South Agricultural Research Institute, Hawassa, Ethiopia; ${ }^{2}$ School of Agricultural Science, Dilla \\ University, Dilla, Ethiopia; ${ }^{3}$ Department of Plant and Horticultural Sciences, Hawassa University, Hawassa, Ethiopia. \\ Email: ${ }^{*}$ albalcha@yahoo.com
}

Received April 21 ${ }^{\text {st }}, 2012$; revised May 19 ${ }^{\text {th }}, 2012$; accepted May $28^{\text {th }}, 2012$

\begin{abstract}
Tef [Eragrostis tef (Zucc.)Trotter] is an ancient and major cereal crop in Ethiopia. Increasing tef grain yield partly requires developing cultivars that are adapted to drought stress environment. An experiment was carried out using 18 tef genotypes grown during September to December, 2010, under two water supply environments (stress during grain filling period, and non-stress) to identify genetic variation, heritability and correlations of grain yield and yield related traits. Broad-sense heritability values under respective stress and non-stress environments were grain yield $\left(\mathrm{g} / \mathrm{m}^{2}\right) 0.80$ and 0.89 , total biomass $\left(\mathrm{g} / \mathrm{m}^{2}\right) 0.89$ and 0.73 , harvest index 0.69 and 0.79 , panicle weight (g/plant) 0.93 and 0.92 , and seed weight (g/plant) 0.96 and 0.86 . The correlations of grain yield under respective stress and non-stress environments were total biomass $r_{p}=0.64, r_{g}=0.70$, and $r_{p}=0.48, r_{g}=0.56$, harvest index $r_{p}=0.70, r_{g}=0.64$, and $r_{p}=0.87, r_{g}=$ 0.90 , panicle weight $r_{p}=0.98, r_{g}=1.00$, and $r_{p}=0.96, r_{g}=1.00$, and seed weight/plant $r_{p}=0.98, r_{g}=1.00$, and $r_{p}=$ $0.90, r_{g}=1.00$. The present experiment showed that either grain yield per se, or seed weight/plant could be used to improve grain yield under stress and non-stress environments.
\end{abstract}

Keywords: Variability; Broad-Sense Heritability; Correlations; Moisture Stress; Eragrostis tef

\section{Introduction}

Tef [Eragrostis tef (Zucc.)Trotter] is an ancient and major cereal crop in Ethiopia. It grows widely from sea level up to $2800 \mathrm{~m}$ above sea level under various rainfall conditions although good productivity is obtained in areas where growing season rainfall exceeds $300 \mathrm{~mm}$ [1]. The average yield of tef is less than 1 tone/ha [2] which is partly attributed to low moisture supply $[3,4]$.

The estimation of genetic parameters for agronomic traits is necessary in the selection of superior genotypes and to evaluate the breeding strategies. The key genetic parameters are heritability, and phenotypic and genetic correlations [5]. The broad-sense heritability is the proportion of phenotypic variation that is due to total (additive and non-additive) genetic effects. It provides an estimate of the genetic advance expected from selection applied to genetic materials under certain environment. The higher the heritability estimates, the simpler are the selection procedures $[6,7]$.

Phenotypic correlation measures how different traits co-vary across phenotypes. A genetic correlation mea-

${ }^{*}$ Corresponding author. sures the degree to which different traits are controlled by the same gene or genes that are closely linked. Early studies in tef showed considerable genetic variation, heritability, and correlations among a range of agronomic traits [8-10]. However, these studies were done under non-moisture stress environments and may not be applicable for drought conditions. The major objectives of the present study were 1) to estimate the variances and broad-sense heritability, and 2) to examine the phenotypic and genetic correlation coefficients for grain yield and yield related traits in tef under moisture stress and non-stress environments.

\section{Materials and Methods}

A field experiment was conducted at Jinka Agricultural Research Center of South Agricultural Research Institute, Ethiopia. Jinka is located at $5^{\circ} 52^{\prime} \mathrm{N}, 36^{\circ} 38^{\prime} \mathrm{E}$, and $1450 \mathrm{~m}$ above sea level with annual average rainfall and temperature of $255 \mathrm{~mm}$ and $22.3^{\circ} \mathrm{C}$, respectively. The soil of the experimental field is sandy loam.

Eighteen tef genotypes were planted at recommended seeding rate of $25 \mathrm{~kg} / \mathrm{ha}$ on September 2, 2010, at the end 
of main rainy season which extends from June to October. The average rainfall and temperature during the experiment duration of September to December, 2010, were 60 $\mathrm{mm}$ and $22.4^{\circ} \mathrm{C}$, respectively. A randomized complete block design with three replications was used under stress and non-stress environments. Each plot consisted of four rows, $1 \mathrm{~m}$ long with spacing of $20 \mathrm{~cm}$ between rows. The distance between replications was $1.5 \mathrm{~m}$ and that between stress and non-stress environments was $4 \mathrm{~m}$. Supplemental irrigation was withdrawn from stress environment after the majority of genotypes attained 50\% flowering stage. Non-stress environment on the other hand received supplemental irrigation from date of planting until physiological maturity. The stress environment was covered with roof of polythene sheet to protect from rainfall and a furrow was prepared around it to prevent water entry. The $40 \mathrm{~kg} / \mathrm{ha} \mathrm{N}$ in the form of urea and diammonium phosphate (DAP) and $60 \mathrm{~kg} / \mathrm{ha} \mathrm{P}_{2} \mathrm{O}_{5}$ (in the form of DAP) were applied at planting. Each plot was kept free from weeds with frequent hand weeding.

At physiological maturity, five random plants within each plot were manually uprooted to determine plant height, panicle weight and seed weight/plant. Grain yield and total biomass were determined after harvesting the whole plot at ground level using sickles and oven drying the grain and straw samples to constant weight at $65^{\circ} \mathrm{C}$. The data were analyzed using GLM procedure of SAS software [11].

Broad-sense heritability $\left(h^{2}\right)$ was calculated as the ratio of the genotypic variance to the phenotypic variance as:

$$
h^{2}=\sigma_{g}^{2} / \sigma_{p}^{2}
$$

where $\sigma_{g}^{2}$ the genotypic variance $[(M S G-M S E) / r], \sigma_{p}^{2}$ the phenotypic variance (genotypic variance plus error variance), $\sigma_{e}^{2}$ error variance (MSE/r), MSG mean square of genotypes, MSE mean square of error and $r$ are number of replications.

The genotypic and phenotypic coefficients of variation were computed according to the methods of Burton [12] and Kumar et al. [13] as:

$$
\begin{aligned}
& G C V=\left(\sigma_{g}^{2}\right)^{0.5} / z \times 100 \\
& P C V=\left(\sigma_{p}^{2}\right)^{0.5} / z \times 100
\end{aligned}
$$

where GCV and $P C V$ are the genotypic and phenotypic coefficient of variation, respectively, and $\sigma_{g}^{2}$ the genotypic variance, $\sigma_{p}^{2}$ the phenotypic variance and $z$ the general mean of a trait.

Genetic and phenotypic correlation coefficients between pairs of traits were calculated using estimates of variances and covariances according to Kibite and Evans [14] as:

$$
r_{g}=C O V_{g x y} /\left(\sigma_{x}^{2} \times \sigma_{y}^{2}\right)^{0.5}
$$

where $r_{g}$ is the genetic correlation coefficient, $C O V_{g x y}$ the genetic covariance between traits $x$ and $y$, and $\sigma_{x}^{2}$ and $\sigma_{y}^{2}$ are the genetic variances for traits $x$ and $y$, respectively. Similar analyses were made for phenotypic correlation coefficients $\left(r_{p}\right)$ using the phenotypic variances and covariances.

\section{Results}

The analysis of variance showed that grain yield and yield related traits were significantly affected by environment, genotype and genotype by environment interactions (Table 1). The effect of genotypes was also significant $(p<0.01)$ for these traits under each environment.

Grain yield $\left(\mathrm{g} / \mathrm{m}^{2}\right)$ ranged from 55 (genotype Denkeye) to 100 (genotype DZ-Cr-387) under stress, and from 108 (genotype Rubicunda) to 203 (genotype DZ-01-974) under non-stress environment. Total biomass $\left(\mathrm{g} / \mathrm{m}^{2}\right)$ ranged from 537 (genotype Addisie) to 866 (genotype DZ-01974) under stress, and from 737 (genotype Rubicunda) to 1056 (genotype DZ-01-974) under non-stress environment (Table 2). Genotypes also showed considerable variations for days to maturity, grain filling period, harvest index, plant height, panicle weight and seed weight/ plant under both stress and non-stress environments.

The $\partial_{g}^{2}$ values were much higher than that of $\partial_{e}^{2}$ for grain yield and yield related traits (Table 3). Both genotypic and phenotypic coefficients of variation were high for grain yield compared to total biomass and harvest index under both environments. The decrease in values of genotypic and phenotypic coefficients of variation for days to maturity, grain filling period, plant height, grain yield, and harvest index, and the increase for total biomass, panicle weight, and seed weight/plant were obtained under stress environment. Broad-sense heritability values under respective stress and non-stress environments were grain yield 0.80 and 0.89 , total biomass 0.89 and 0.73 , harvest index 0.69 and 0.79 , panicle weight 0.93 and 0.92 , and seed weight/plant 0.96 and 0.86 .

The correlations of grain yield in respective stress and non-stress environments were total biomass $r_{p}=0.64, r_{g}$ $=0.70$, and $r_{p}=0.48, r_{g}=0.56$, harvest index $r_{p}=0.70$, $r_{g}=0.64$, and $r_{p}=0.87, r_{g}=0.90$, panicle weight $r_{p}=0.98$, $r_{g}=1.00$, and $r_{p}=0.96, r_{g}=1.00$, and seed weight $/$ plant $r_{p}$ $=0.98, r_{g}=1.00$, and $r_{p}=0.90, r_{g}=1.00$ (Table 4). The correlations of total biomass in respective stress and non-stress environments were panicle weight $r_{p}=0.64, r_{g}$ $=0.68$ and $r_{p}=0.33, r_{g}=0.38$, and seed weight/plant $r_{p}=$ $0.58, r_{g}=64$, and $r_{p}=0.44, r_{g}=0.55$. The correlations of harvest index in respective stress and non-stress environments were grain filling period $r_{p}=-0.54, r_{g}=-0.96$, 
Table 1. Significance of mean squares for eight grain yield and yield related traits for 18 tef genotypes and two water supply environments (stress and non-stress).

\begin{tabular}{|c|c|c|c|c|c|c|c|c|c|}
\hline Source of variation & D.F & $\begin{array}{l}\text { Days to } \\
\text { maturity }\end{array}$ & $\begin{array}{l}\text { Grain filling } \\
\text { period }\end{array}$ & $\begin{array}{l}\text { Grain yield } \\
\left(\mathrm{g} / \mathrm{m}^{2}\right)\end{array}$ & $\begin{array}{l}\text { Total biomass } \\
\left(\mathrm{g} / \mathrm{m}^{2}\right)\end{array}$ & $\begin{array}{l}\text { Harvest } \\
\text { index }^{\mathrm{a}}\end{array}$ & $\begin{array}{l}\text { Plant height } \\
\quad(\mathrm{cm})\end{array}$ & $\begin{array}{c}\text { Panicle } \\
\text { weight } \\
\text { (g/plant) }\end{array}$ & $\begin{array}{l}\text { Seed weight } \\
\text { (g/plant) }\end{array}$ \\
\hline Replication/E & 4 & $3.30 \mathrm{~ns}$ & $9.20 \mathrm{~ns}$ & $412 \mathrm{~ns}$ & $3432 \mathrm{~ns}$ & $9.92 *$ & $11.54 \mathrm{~ns}$ & $0.025 \mathrm{~ns}$ & $0.033 \mathrm{~ns}$ \\
\hline Environment (E) & 1 & $4156.48^{* *}$ & $4009^{* *}$ & $152701 * *$ & $1302997 * *$ & $922.18^{* *}$ & $5070.37 * *$ & $1.668^{* *}$ & $2.367^{* *}$ \\
\hline Genotype (G) & 17 & $116.55^{* *}$ & $40.14 * *$ & $2616 * *$ & $31678 * *$ & $22.80^{* *}$ & $432.59 * *$ & $0.432 * *$ & $0.247 * *$ \\
\hline $\mathrm{G} \times \mathrm{E}$ & 17 & $22.50^{* *}$ & $22.06 * *$ & $607^{* *}$ & $14537^{* *}$ & $9.56^{* *}$ & $46.51^{*}$ & $0.044^{* *}$ & $0.041^{* *}$ \\
\hline Error & 68 & 6.33 & 7.64 & 199 & 4364 & 3.80 & 25.71 & 0.018 & 0.015 \\
\hline $\mathrm{CV}, \%$ & & 2.85 & 5.98 & 12.90 & 8.47 & 14.30 & 6.56 & 9.62 & 30.10 \\
\hline \multicolumn{10}{|l|}{ Stress } \\
\hline Replication & 2 & $5.69 \mathrm{~ns}$ & $12.24 \mathrm{~ns}$ & $735^{* *}$ & $2869 \mathrm{~ns}$ & $18.04 * *$ & $7.39 \mathrm{~ns}$ & $0.048 \mathrm{~ns}$ & $0.003 \mathrm{~ns}$ \\
\hline Genotype & 17 & $47.08^{* *}$ & $22.27 * *$ & $593 * *$ & $23668 * *$ & $8.38^{* *}$ & $140.52 * *$ & $0.222 * *$ & $0.112^{* *}$ \\
\hline Error & 34 & 7.41 & 9.22 & 116 & 2533 & 2.64 & 28.68 & 0.015 & 0.005 \\
\hline $\mathrm{CV}, \%$ & & 3.32 & 7.57 & 11.44 & 7.51 & 15.16 & 7.61 & 9.61 & 27.08 \\
\hline \multicolumn{10}{|l|}{ Non-stress } \\
\hline Replication & 2 & $0.91 \mathrm{~ns}$ & $6.17 \mathrm{~ns}$ & $89 \mathrm{~ns}$ & $3995 \mathrm{~ns}$ & $1.8 \mathrm{~ns}$ & $15.69 \mathrm{~ns}$ & $0.003 \mathrm{~ns}$ & $0.064 \mathrm{~ns}$ \\
\hline Genotype & 17 & $91.97 * *$ & $39.93 * *$ & $2630 * *$ & $22547 * *$ & $23.98 * *$ & $338.58 * *$ & $0.254 * *$ & $0.177 * *$ \\
\hline Error & 34 & 5.24 & 6.05 & 282 & 6195 & 4.96 & 22.74 & 0.021 & 0.025 \\
\hline $\mathrm{CV}, \%$ & & 2.43 & 4.70 & 15.10 & 8.84 & 13.45 & 5.67 & 9.56 & 28.44 \\
\hline
\end{tabular}

${ }^{\mathrm{a}}$ Harvest index was multiplied by $10^{-4} ; *, * *=$ significant at $p<0.05$ and $p<0.01$, respectively; ns $=$ not significant.

Table 2. Mean values of eight grain yield and yield related traits of 18 tef genotypes grown under stress (S) and non-stress (N) environments.

\begin{tabular}{|c|c|c|c|c|c|c|c|c|c|c|c|c|c|c|c|c|}
\hline \multirow{2}{*}{ Genotypes $^{1}$} & \multicolumn{2}{|c|}{ DTM } & \multicolumn{2}{|c|}{ GFP } & \multicolumn{2}{|c|}{ GY } & \multicolumn{2}{|c|}{ TB } & \multicolumn{2}{|c|}{$\mathrm{HI}$} & \multicolumn{2}{|c|}{ PHT } & \multicolumn{2}{|c|}{ PW } & \multicolumn{2}{|c|}{ SW } \\
\hline & $\mathrm{S}$ & $\mathrm{N}$ & $\mathrm{S}$ & $\mathrm{N}$ & $S$ & $\mathrm{~N}$ & $\mathrm{~S}$ & $\mathrm{~N}$ & $\mathrm{~S}$ & $\mathrm{~N}$ & $S$ & $\mathrm{~N}$ & $S$ & $\mathrm{~N}$ & $S$ & $\mathrm{~N}$ \\
\hline Addisie & 86 & 98 & 42 & 53 & 57 & 111 & 537 & 989 & 0.11 & 0.11 & 60 & 72 & 0.91 & 1.13 & 0.06 & 0.32 \\
\hline Denkeye & 87 & 95 & 47 & 55 & 55 & 120 & 667 & 891 & 0.08 & 0.13 & 60 & 74 & 0.92 & 1.26 & 0.05 & 0.29 \\
\hline Enatite & 82 & 93 & 40 & 52 & 65 & 138 & 651 & 861 & 0.10 & 0.16 & 69 & 86 & 1.17 & 1.48 & 0.13 & 0.50 \\
\hline Gofarie & 83 & 93 & 42 & 51 & 59 & 118 & 607 & 925 & 0.10 & 0.13 & 64 & 76 & 1.07 & 1.15 & 0.09 & 0.19 \\
\hline Gommadie & 88 & 102 & 42 & 56 & 57 & 113 & 632 & 935 & 0.09 & 0.12 & 71 & 76 & 1.02 & 1.05 & 0.07 & 0.35 \\
\hline Manya & 79 & 94 & 37 & 52 & 61 & 121 & 662 & 795 & 0.09 & 0.15 & 67 & 81 & 1.07 & 1.31 & 0.09 & 0.35 \\
\hline Rubicunda & 86 & 96 & 44 & 53 & 63 & 108 & 630 & 737 & 0.10 & 0.15 & 60 & 71 & 1.12 & 1.41 & 0.11 & 0.46 \\
\hline Variegata & 80 & 94 & 39 & 52 & 62 & 131 & 707 & 793 & 0.09 & 0.17 & 62 & 66 & 1.07 & 1.36 & 0.11 & 0.45 \\
\hline DZ-01-99 & 83 & 96 & 40 & 54 & 69 & 137 & 550 & 808 & 0.13 & 0.17 & 73 & 85 & 1.29 & 1.43 & 0.27 & 0.47 \\
\hline DZ-01-196 & 83 & 91 & 42 & 50 & 74 & 148 & 728 & 807 & 0.10 & 0.18 & 73 & 85 & 1.44 & 1.54 & 0.39 & 0.55 \\
\hline DZ-01-354 & 80 & 94 & 39 & 52 & 68 & 158 & 731 & 844 & 0.09 & 0.19 & 75 & 90 & 1.13 & 1.64 & 0.17 & 0.59 \\
\hline DZ-01-787 & 82 & 94 & 39 & 52 & 92 & 164 & 755 & 981 & 0.12 & 0.17 & 76 & 86 & 1.63 & 1.68 & 0.52 & 0.63 \\
\hline DZ-01-974 & 79 & 95 & 39 & 54 & 94 & 203 & 866 & 1056 & 0.11 & 0.19 & 81 & 97 & 1.76 & 2.04 & 0.55 & 1.26 \\
\hline DZ-01-1285 & 89 & 107 & 39 & 57 & 90 & 157 & 688 & 889 & 0.13 & 0.18 & 77 & 86 & 1.52 & 1.60 & 0.47 & 0.59 \\
\hline DZ-01-1681 & 80 & 91 & 40 & 51 & 72 & 176 & 703 & 894 & 0.10 & 0.20 & 76 & 93 & 1.39 & 1.79 & 0.23 & 0.73 \\
\hline DZ-Cr-255 & 77 & 80 & 38 & 41 & 68 & 186 & 575 & 873 & 0.12 & 0.21 & 78 & 105 & 1.23 & 1.92 & 0.21 & 0.75 \\
\hline DZ-Cr-358 & 75 & 88 & 35 & 48 & 82 & 165 & 569 & 912 & 0.14 & 0.19 & 77 & 100 & 1.47 & 1.72 & 0.45 & 0.69 \\
\hline DZ-Cr-387 & 79 & 99 & 38 & 57 & 100 & 190 & 810 & 1031 & 0.12 & 0.18 & 67 & 85 & 1.78 & 1.95 & 0.62 & 0.75 \\
\hline Mean & 82 & 94 & 40 & 52 & 72 & 147 & 670 & 890 & 0.11 & 0.17 & 70 & 84 & 1.28 & 1.53 & 0.25 & 0.55 \\
\hline $\mathrm{LSD}_{0.05}$ & 2.60 & 2.18 & 2.89 & 2.34 & 10.28 & 16.01 & 47.97 & 75.03 & 0.015 & 0.021 & 5.11 & 4.55 & 0.12 & 0.14 & 0.066 & 0.149 \\
\hline
\end{tabular}

${ }^{1}$ Genotypes Addisie to Variegata are landraces and DZ-01-99 to DZ-Cr-387 are improved cultivars; DTM = days to maturity; GFP = grain filling period; GY = grain yield $\left(\mathrm{g} / \mathrm{m}^{2}\right) ; \mathrm{TB}=$ total biomass $\left(\mathrm{g} / \mathrm{m}^{2}\right) ; \mathrm{HI}=$ harvest index; PHT = plant height $(\mathrm{cm}) ; \mathrm{PW}=$ panicle weight $(\mathrm{g} / \mathrm{plant}) ; \mathrm{SW}=\mathrm{seed}$ weight $(\mathrm{g} / \mathrm{plant})$. 
Table 3. Estimates of variances, coefficients of variations and broad-sense heritability $\left(h^{2}\right)$ for eight grain yield and yield related traits across 18 tef genotypes under stress $(\mathrm{S})$ and non-stress $(\mathrm{N})$ environments.

\begin{tabular}{|c|c|c|c|c|c|c|c|}
\hline Traits & Environment & $\mathrm{\partial}_{g}^{2}$ & $\partial_{p}^{2}$ & $\partial_{e}^{2}$ & $\mathrm{GCV}$ & PCV & $h^{2}$ \\
\hline \multirow[t]{2}{*}{ Days to maturity } & $\mathrm{S}$ & 13.22 & 15.69 & 2.47 & 4.43 & 4.83 & 0.84 \\
\hline & $\mathrm{N}$ & 28.91 & 30.66 & 1.75 & 5.69 & 5.86 & 0.94 \\
\hline \multirow[t]{2}{*}{ Grain filling period } & $\mathrm{S}$ & 4.35 & 7.42 & 3.08 & 5.20 & 6.80 & 0.59 \\
\hline & $\mathrm{N}$ & 11.29 & 13.31 & 2.02 & 6.43 & 6.98 & 0.85 \\
\hline \multirow[t]{2}{*}{ Grain yield $\left(\mathrm{g} / \mathrm{m}^{2}\right)$} & $\mathrm{S}$ & 159 & 198 & 39 & 17.60 & 19.6 & 0.80 \\
\hline & $\mathrm{N}$ & 783 & 877 & 94 & 19.10 & 20.20 & 0.89 \\
\hline \multirow[t]{2}{*}{ Total biomass $\left(\mathrm{g} / \mathrm{m}^{2}\right)$} & $\mathrm{S}$ & 7045 & 7889 & 844 & 12.50 & 13.30 & 0.89 \\
\hline & $\mathrm{N}$ & 5451 & 7516 & 2065 & 8.30 & 9.74 & 0.73 \\
\hline \multirow[t]{2}{*}{ Harvest index } & $\mathrm{S}$ & 1.91 & 2.79 & 0.88 & 12.90 & 15.60 & 0.69 \\
\hline & $\mathrm{N}$ & 6.34 & 7.99 & 1.66 & 15.20 & 17.10 & 0.79 \\
\hline \multirow[t]{2}{*}{ Plant height (cm) } & $\mathrm{S}$ & 37.00 & 46.84 & 9.56 & 8.67 & 9.72 & 0.80 \\
\hline & $\mathrm{N}$ & 105 & 113 & 7.58 & 12.20 & 12.60 & 0.93 \\
\hline \multirow[t]{2}{*}{ Panicle weight (g/plant) } & $\mathrm{S}$ & 0.069 & 0.074 & 0.005 & 20.60 & 21.30 & 0.93 \\
\hline & $\mathrm{N}$ & 0.078 & 0.085 & 0.007 & 18.30 & 19.10 & 0.92 \\
\hline \multirow[t]{2}{*}{ Seed weight (g/plant) } & $\mathrm{S}$ & 0.036 & 0.037 & 0.002 & 74.10 & 75.70 & 0.96 \\
\hline & $\mathrm{N}$ & 0.051 & 0.059 & 0.008 & 40.90 & 44.10 & 0.86 \\
\hline
\end{tabular}

Table 4. Phenotypic $\left(r_{p}\right)$ and genetic $\left(r_{g}\right)$ correlation coefficients for eight grain yield and yield related traits across 18 tef genotypes under stress (below diagonal) and non-stress (above diagonal) environments.

\begin{tabular}{|c|c|c|c|c|c|c|c|c|c|c|}
\hline & Traits & & 1 & 2 & 3 & 4 & 5 & 6 & 7 & 8 \\
\hline \multirow[t]{2}{*}{1} & Days to maturity & $r_{p}$ & & $0.93 * *$ & $-0.30 \mathrm{~ns}$ & $0.18 \mathrm{~ns}$ & $-0.45 \mathrm{~ns}$ & $-0.50^{*}$ & $-0.34 \mathrm{~ns}$ & $-0.20 \mathrm{~ns}$ \\
\hline & & $r_{g}$ & & $0.96^{* *}$ & $-0.33 \mathrm{~ns}$ & $0.24 \mathrm{~ns}$ & $-0.55^{*}$ & $-0.53^{*}$ & $-0.38 \mathrm{~ns}$ & $-0.22 \mathrm{~ns}$ \\
\hline \multirow[t]{2}{*}{2} & Grain filling period & $r_{p}$ & $0.75^{* *}$ & & $-0.24 \mathrm{~ns}$ & $0.23 \mathrm{~ns}$ & $-0.43 \mathrm{~ns}$ & $-0.52^{*}$ & $-0.26 \mathrm{~ns}$ & $-0.13 \mathrm{~ns}$ \\
\hline & & $r_{g}$ & $0.75^{* *}$ & & $-0.30 \mathrm{~ns}$ & $0.32 \mathrm{~ns}$ & $-0.58^{*}$ & $-0.58^{*}$ & $-0.33 \mathrm{~ns}$ & $-0.14 \mathrm{~ns}$ \\
\hline \multirow[t]{2}{*}{3} & Grain yield $\left(\mathrm{g} / \mathrm{m}^{2}\right)$ & $r_{p}$ & $-0.33 \mathrm{~ns}$ & $-0.49 *$ & & $0.48^{*}$ & $0.87 * *$ & $0.82 * *$ & $0.96 * *$ & $0.90 * *$ \\
\hline & & $r_{g}$ & $-0.43 \mathrm{~ns}$ & $-0.75^{* *}$ & & $0.56^{*}$ & $0.90 * *$ & $0.90 * *$ & $1.00 * *$ & $1.00 * *$ \\
\hline \multirow[t]{2}{*}{4} & Total biomass $\left(\mathrm{g} / \mathrm{m}^{2}\right)$ & $r_{p}$ & $-0.17 \mathrm{~ns}$ & $-0.12 \mathrm{~ns}$ & $0.64 * *$ & & $-0.01 \mathrm{~ns}$ & $0.27 \mathrm{~ns}$ & $0.33 \mathrm{~ns}$ & $0.44 \mathrm{~ns}$ \\
\hline & & $r_{g}$ & $-0.18 \mathrm{~ns}$ & $-0.11 \mathrm{~ns}$ & $0.70 * *$ & & $0.15 \mathrm{~ns}$ & $0.32 \mathrm{~ns}$ & $0.38 \mathrm{~ns}$ & $0.55^{*}$ \\
\hline \multirow[t]{2}{*}{5} & Harvest index & $r_{p}$ & $-0.30 \mathrm{~ns}$ & $-0.54 *$ & $0.70 * *$ & $-0.10 \mathrm{~ns}$ & & $0.80 * *$ & $0.90 * *$ & $0.77 * *$ \\
\hline & & $r_{g}$ & $-0.45 \mathrm{~ns}$ & $-0.96^{* *}$ & $0.64 * *$ & $-0.10 \mathrm{~ns}$ & & $0.95 * *$ & $1.00 * *$ & $0.92 * *$ \\
\hline \multirow[t]{2}{*}{6} & Plant height $(\mathrm{cm})$ & $r_{p}$ & $-0.40 \mathrm{~ns}$ & $-0.56^{*}$ & $0.62 * *$ & $0.30 \mathrm{~ns}$ & $0.56^{*}$ & & $0.79 * *$ & $0.72 * *$ \\
\hline & & $r_{g}$ & $-0.54 *$ & $-0.87 * *$ & $0.76^{* *}$ & $0.35 \mathrm{~ns}$ & $0.73 * *$ & & $0.88 * *$ & $0.82 * *$ \\
\hline \multirow[t]{2}{*}{7} & Panicle weight (g/plant) & $r_{p}$ & $-0.39 \mathrm{~ns}$ & $-0.48^{*}$ & $0.98 * *$ & $0.64 * *$ & $0.67 * *$ & $0.67 * *$ & & $0.91 * *$ \\
\hline & & $r_{g}$ & $-0.46^{*}$ & $-0.66^{* *}$ & $1.00 * *$ & $0.68 * *$ & $0.82 * *$ & $0.73 * *$ & & $1.00 * *$ \\
\hline \multirow[t]{2}{*}{8} & Seed weight (g/plant) & $r_{p}$ & $-0.34 \mathrm{~ns}$ & $-0.47 *$ & $0.98 * *$ & $0.58 *$ & $0.74 * *$ & $0.63 *$ & $0.98 * *$ & \\
\hline & & $r_{g}$ & $-0.38 \mathrm{~ns}$ & $-0.63 * *$ & $1.00 * *$ & $0.64 * *$ & $0.91 * *$ & $0.71 * *$ & $1.00 * *$ & \\
\hline
\end{tabular}

*, ** = significant at $p<0.05$ and $p<0.01$, respectively; ns $=$ not significant. 
and $r_{p}=-0.43, r_{g}=-0.58$, panicle weight $r_{p}=0.67, r_{g}=$ 0.82 , and $r_{p}=0.90, r_{g}=1.00$, and seed weight/plant $r_{p}=$ $0.74, r_{g}=91$, and $r_{p}=0.77, r_{g}=0.92$.

\section{Discussion}

The reduction in performance due to moisture stress observed in present experiment agrees with the previous studies in tef [15], and wheat [16,17]. Water deficit occurring from flowering to maturity usually results in poor assimilation, reduced translocation of photosynthates to the grain and higher respiratory losses $[18,19]$. Consequently, the effect of moisture stress was manifested in low panicle weight, seed weight/plant and grain yield. The highest grain yield was obtained under both environments for genotypes DZ-01-974 and DZ-Cr-387 indicating that these genotypes may be used in future breeding programs to improve grain yield under stress and non-stress environments.

In the present experiment, the phenotypic coefficient of variation was higher than the genotypic coefficient of variation, but in most cases the two values differed only slightly, indicating small environmental effects in estimating these traits. On the other hand, the high broadsense heritability observed in this study suggests the feasibility of selection to improve tef grain yield under stress as well as non-stress environments. However, heritability is a value of a character only for the population and the environment to which the genetic materials are subjected [5]. Thus, value of heritability depends on the magnitude of all the components of variance, and a change in any of these will affect it. As to the present experiment, the decrease in broad-sense heritability under stress environment for grain yield [20,21], and harvest index and plant height [21,22], and the increase in that of total biomass [22] has been reported for wheat.

The negative correlation $\left(r_{g}=-0.75, r_{p}=-0.49\right)$ between grain yield and grain filling period under stress environment suggests the possibility of using rapid maturity to escape the effects of drought [1]. The importance of total biomass to improve grain yield was low $\left(r_{p}\right.$ $\left.=0.48, r_{g}=0.56\right)$ under non-stress compared to stress environment $\left(r_{p}=0.64, r_{g}=0.70\right)$. This could be related to low variability of total biomass under non-stress environment as was suggested by Donald and Hamblin [23]. On the other hand, the strong correlation between grain yield and seed weight/plant suggests that either grain yield per se or the latter trait can be used to improve grain yield under stress and non-stress environments. However, high error coefficient of variation associated to seed weight/plant suggests a careful handling of it to reduce sampling error.

\section{Acknowledgements}

The authors thank South Agricultural Research Institute for the financial support for the project.

\section{REFERENCES}

[1] S. Ketema, "Phenotypic Variations in Tef (Eragrostis tef) Germplasm-Morphological and Agronomic Traits," A Catalon Technical Manual No. 6, Institute of Agricultural Research, Addis Ababa, 1993.

[2] CSA (Central Statistical Authority), "Agricultural Sample Survey, 2001/02 Area and Production for Major Crops Private Peasant Holdings," Vol. I, Statistical Bulletin No. 227, 2003.

[3] B. Shiferaw, "A Study of Drought Tolerance in Tef (Eragrostis tef (Zucc.)Trotter)," Ph.D. Thesis, University of London, London, 1991.

[4] M. Ayele and S. Ketema, "Potentials of Physiological Traits in Breeding of Tef (Eragrostis tef) for Drought Resistance with Emphasis on Excised-Leaf Water Loss," Proceedings of the Sixth Annual Conference of the Crop Science Society of Ethiopia, Addis Ababa, 1995.

[5] D. S. Falconer, "Introduction to Quantitative Genetics," 3rd Edition, Longman Scientific and Technical, Essex, 1989.

[6] N. Ahmed, M. A. Chowdhry, I. Khaliq and M. Maekawa, "The Inheritance of Yield and Yield Components of Five Wheat Hybrid Populations under Drought Conditions," Indonesian Journal of Agricultural Sciences, Vol. 8, 2007, pp. 53-59.

[7] H. Khan, H. Rahman, H. Ahmed and H. Ali, "Magnitude of Heterosis and Heritability in Sunflower over Environments," Pakistan Journal of Botany, Vol. 1, 2008, pp. 301-308.

[8] K. Assefa, S. Ketema, H. Tefera, H. T. Nguyen, A. Blum, M. Ayele, G. Bai, B. Simane and T. Kefyalew, "Diversity among Germplasm Lines of the Ethiopian Cereal Tef [Eragrostis tef (Zucc.)Trotter]," Euphytica, Vol. 106, No. 1, 1999, pp. 87-97. doi:10.1023/A:1003582431039

[9] F. Hundera, H. Tefera, K. Assefa and T. Kefyalew, "Genetic Variability and Correlation of Morpho-Agronomic Characters in Tef Landraces," Tropical Science, Vol. 39, 1999, pp. 140-146.

[10] A. Balcha, R. Gretzmacher and J. Vollmann, "Estimation of Genetic Parameters for Grain Yield and Yield Related Traits in Tef [Eragrostis tef (Zucc.)Trotter]," Journal of Genetics and Breeding, Vol. 57, 2003, pp. 251-257.

[11] SAS Institute, "The SAS System for Windows, V6.12," Carry, NC, 1996.

[12] G. W. Burton, "Quantitative Inheritance in Pearl Millet (Pennisetum glaucum S. \& H.)," Agronomy Journal, Vol. 43, No. 9, 1952, pp. 409-417. doi:10.2134/agronj1951.00021962004300090001x

[13] A. Kumar, S. C. Misra, Y. P. Singh and B. P. S. Chauhan, "Variability and Correlation Studies in Triticale," Journal of Maharashtra Agricultural University, Vol. 10, 1985, pp. 273-275.

[14] S. Kibite, and L. W. Evans, "Causes of Negative Correla- 
tions between Grain Yield and Grain Protein Concentration in Common Wheat," Euphytica, Vol. 33, No. 3, 1984, pp. 801-810. doi:10.1007/BF00021906

[15] T. Tefera, H. Tefera, B. Simane and M. Tuinstra, "The Influence of Drought Stress on Yield of Tef (Eragrostis tef)," Tropical Science, Vol. 40, 2000, pp. 40-45.

[16] M. Golabadi, A. Arzani and S. M. M. Maibody, "Evaluation of Variation among Durum Wheat F3 Families for Grain Yield and Its Components under Normal and Water-Stress Field Conditions," Czech Journal of Genetics and Plant Breeding, Vol. 41, 2005, pp. 263-267.

[17] A. Nouri-Ganbalani, G. Nouri-Ganbalani and D. Hassanpanah, "Effects of Drought Stress Condition on the Yield and Yield Components of Advanced Wheat Genotypes in Ardabil," Journal of Food, Agriculture \& Environment, Vol. 7, No. 3-4, 2009, pp. 228-234.

[18] K. Al-Khatib and G. M. Paulsen, "Mode of High Temperature to Wheat during Grain Development," Physiologia Plantarum, Vol. 61, No. 3, 1984, pp. 363-368. doi:10.1111/j.1399-3054.1984.tb06341.x
[19] L. Shpiler and A. Blum, "Heat Tolerance to Yield and Its Components in Different Wheat Cultivars," Euphytica, Vol. 51, No. 3, 1991, pp. 257-263. doi:10.1007/BF00039727

[20] N. Khan and F. N. Naqvi, "Heritability of Morphological Traits in Bread Wheat Advanced Lines under Irrigated and Non-Irrigated Conditions," Asian Journal of Agricultural Sciences, Vol. 3, 2011, pp. 215-222.

[21] S. Taheri, J. Saba, F. Shekari and T. L. Abdullah, "Effects of Drought Stress Condition on the Yield of Spring Wheat (Triticum aestivum) Lines," African Journal of Biotechnology, Vol. 10, 2011, pp. 18339-18348.

[22] M. A. Shah, and V. S. Deora, "Genetic Variability and Association Studies in Wheat for Grain Yield and Temperature Tolerance Parameters," Indian Journal of Agricultural Research, Vol. 36, 2002, pp. 172-176.

[23] C. M. Donald and J. Hamblin, "The Biological Yield and Harvest Index of Cereals as Gronomic and Plant Breeding Criteria," Advances in Agronomy, Vol. 28, 1976, pp. 336405. doi:10.1016/S0065-2113(08)60559-3 